\title{
A NEW CHRONOLOGY FOR POLOLU VALLEY, HAWAI'I ISLAND: OCCUPATIONAL HISTORY AND AGRICULTURAL DEVELOPMENT
}

\author{
Julie S Field \\ Department of Anthropology, The Ohio State University, 244 Lord Hall, 124 W. 17th Ave., Columbus, Ohio, USA. \\ Corresponding author. Email: field.59@osu.edu. \\ Michael W Graves \\ Department of Anthropology, University of New Mexico, MSC01 1040, 1 University of New Mexico, Albuquerque, New \\ Mexico, USA. Email: mwgraves@unm.edu.
}

\begin{abstract}
A reanalysis of the chronology of Pololu Valley, located in the district of Kohala on Hawai $i$ Island, is presented using standard radiocarbon and accelerator mass spectrometry (AMS) dating. Using curated materials from the 1970s, Pololu is reassessed and found to have the earliest coastal occupations in this part of Hawai ${ }^{\circ} \mathrm{i}$, beginning about AD 1300. Occupations at the dunes and in the valley interior are investigated, as are dryland and wetland field agricultural systems. These data provide a refined model for expansion and intensification of agricultural production in the 15th-17th centuries, and link this remote valley to demographic and sociopolitical trends that were occurring in the rest of Hawai $i$.
\end{abstract}

\section{INTRODUCTION}

Archaeological research in the Hawaiian Islands has long sought to understand the complex relationships between population size and distribution, local environments, and the development of agricultural production systems (Earle 1980; Cordy 1981; Hommon 1986; Kirch 1990; Allen 1991; Dye 1994b; Rosendahl 1994; Ladefoged and Graves 2006). In the late 1960s, researchers from the University of Hawai ' $i$ initiated a multiyear research project focused on the prehistory of the district of Kohala, located on the northern tip of the Island of Hawai' $i$. This program was one of the first regional-level studies in Hawai ' $i$, and it was unique in its focus on both habitations and agricultural systems. One portion of this program was focused on the leeward (drier) western portion of the district, the ahириа ' $a$ (term for the traditional territorial unit representing a community) of Lapakahi (Rosendahl 1972; Tuggle and Griffin 1973). Subsequently, a program of research directed by H David Tuggle and Myra Tomonari-Tuggle was initiated on the windward (wetter), eastern portion of the district, focused on 2 valleys, the ahupua ' $a$ of Pololu and Honokane. Their results indicated that these 2 deep windward valleys had been settled in the 15th century and were dedicated to the production of Hawaiian taro [kalo] (Colocasia esculenta) and other crops (Figure 1). They also noted that the agricultural systems put in place in Pololu were designed for non-irrigated dryland cultivation, but that in certain areas irrigated wetland production had been introduced, and then later abandoned, at some point in late prehistory (Tomonari-Tuggle n.d.; Tuggle 1976; Tuggle and TomonariTuggle 1980).

Recent interest in the prehistoric agricultural production of the region has continued with the investigation of the Kohala Field System, located on the western slope of the Kohala Mountains. Mapping and excavation of agricultural features, religious structures, and habitations within the southern portion of this system have allowed for detailed analyses of agricultural investment in Hawaiian prehistory (Ladefoged et al. 1996, 2003, 2008; Ladefoged and Graves 2000; Mulrooney and Ladefoged 2005), and also indicated regional trends in sociopolitical systems that likely influenced the distribution of populations and the timing of agricultural expansion and intensification (Ladefoged and Graves 2006). This study has implications for other parts of Hawai ' $i$, such as the Kona district to the south (Newman 1970) and on Maui, where similar agricultural systems developed (Coil 2004; Kirch et al. 2005), and also for the windward Kohala chronologies that were developed $30 \mathrm{yr}$ ago. 

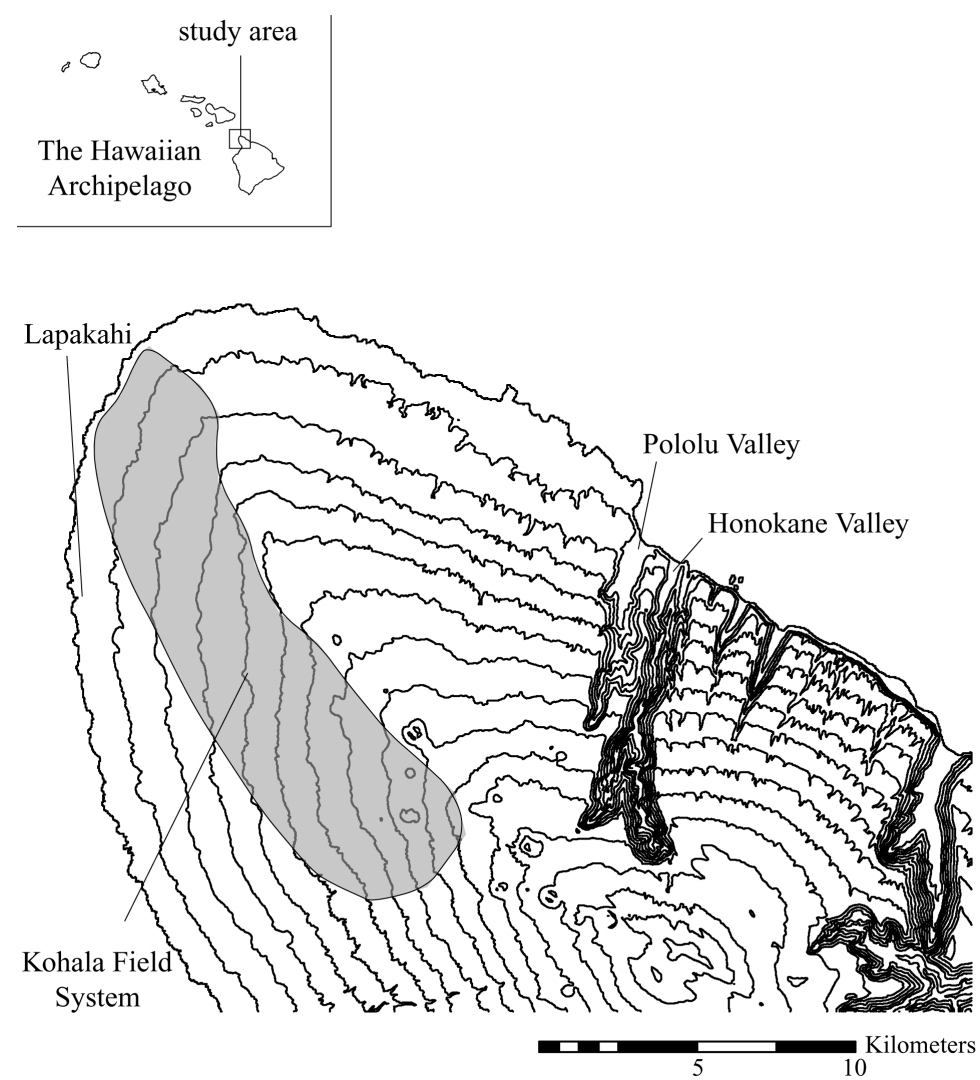

Figure 1 Map of the Kohala district with the location of Pololu Valley indicated. Other locations mentioned in text are also shown. Topographic contour $100 \mathrm{~m}$.

The methods used to date archaeological sites in Hawai' $i$ have changed significantly since the 1970s. Foremost of these is the rejection of volcanic glass dates based on the obsidian hydration method, which has been found to be unreliable (Graves and Ladefoged 1994; Tuggle and Spriggs 2002). Additionally, more conservative sampling requirements for radiocarbon dating and the palynological analysis of cores from wetland contexts in both Hawai' $i$ and East Polynesia have indicated that the dates for colonization are considerably later than thought, most likely sometime after AD 800 (Anderson and Sinoto 2002; Athens et al. 2002; Tuggle and Spriggs 2002; Burney and Burney 2003). These dates indicate that many of the models developed since the 1950s to explain changes in traditional Hawaiian society must be recalibrated and reconfigured in order to integrate a shorter chronology. Because of this, there is a need to redate many of the well-known and potentially early sites in the Hawaiian archipelago, especially if datable samples remain in curated collections (Dye 1994a, 2000). We also wish to stress that later chronologies that are based on obsidian hydration dates must be similarly revised or discarded. This is the case for the coastal occupations at Lapakahi, which were dated to AD 1300 using this method (Tuggle and Griffin 1973:55-59). Despite their dubious quality, these dates persist in the literature and developmental models for the region (Tuggle and Tomonari-Tuggle 1980:303; Rosendahl 1994:20; Ladefoged and Graves 2000: 430).

This paper assesses the chronology of Pololu Valley via a suite of accelerator mass spectrometry (AMS) and standard ${ }^{14} \mathrm{C}$ dates derived from samples collected originally in the early 1970s. The 
need for this review is clear, as nearly all of the existing dates from Pololu were obtained from volcanic glass hydration analyses (Tuggle 1976; Graves and Ladefoged 1994). The inclusion of a redated Pololu into the Hawaiian chronology provides a significant data set for the region, spanning coastal dune occupations, the establishment of early agricultural areas, and the construction of irrigated terraces. It also allows for a fuller understanding of the economics of traditional Hawaiian districts. As the district of Kohala includes both leeward and windward environments, the addition of Pololu provides a rare opportunity to examine the concurrent establishment and expansion of 2 agricultural systems: one dedicated to the dryland production of sweet potato, the other for wetland and dryland kalo. Pololu's well-studied agricultural system also has the potential to inform on ecological variability and risk-taking in prehistory, especially the construction of agricultural features in areas that were less than optimal. Similar work done in the Kohala Field System (Ladefoged et al. 2008) and more recently in Wailau Valley on Moloka'i (McElroy 2007) demonstrate that these relationships were dynamic, and connected to local variations in rainfall, stream flow, soil quality, and productive potential. The Pololu data provide another opportunity to investigate agricultural decision making and investment in Hawaiian prehistory, and relate these decisions to trajectories of change in populations and socio-political systems in other parts of the district and ultimately, in Hawai 'i.

\section{THE 1972-1973 INVESTIGATIONS}

Prior to 1970, archaeological research in the district of Kohala had been focused on the leeward coast, including the village at Lapakahi (Tuggle and Griffin 1973) (Figure 1). Investigation of the windward side of Kohala was both conceptually and academically linked, as both programs were funded by the National Science Foundation as Research Experience for Undergraduates Sites, and were part of a much larger program of study on lands held by the State of Hawai ' $i$, Parker Ranch, and Bishop Estate/Kamehameha schools. The goal of the research was the documentation of prehistoric habitation and agriculture in both the windward and leeward sides of the district, and the accumulation of data that could ultimately inform upon a general model of Hawaiian prehistory and state formation. Survey, mapping, and excavation of Pololu, Honokane, and Honopue valleys was completed in 1972-1974. Several large archaeological complexes were investigated in each valley. Excavations at Pololu were conducted on the dunes at the mouth of the valley, and on large terrace agricultural complexes on the valley floor and in the remote upper reaches of the valley (Figure 2). Historic-era habitations with diverse collections of Euroamerican and Asian goods were also investigated (Graves et al. 2006). As a result, the research at Pololu produced a rich archaeological collection and volumes of related data and analyses. Two unpublished manuscripts were produced in the following years (Tomonari-Tuggle n.d.; Tuggle 1976) as well as an article in an academic journal (Tuggle and Tomonari-Tuggle 1980). These documents allow for the continued study of the existing collections, and also provide a foundation for additional research.

\section{RESULTS}

\section{Redating the Pololu Dunes}

Tuggle and Tomonari-Tuggle identified the Pololu Dunes as the earliest locale for habitation in the valley. Lying directly above the beach, the dunes reach approximately $30 \mathrm{~m}$ above sea level at their highest point and extend parallel to the beach for about $400 \mathrm{~m}$. They are composed of eroded alluvial deposits originating in the intermittent flood sequences of Pololu Stream (Presley 1999), which were then redeposited along the shoreline. Wind and wave action have pushed the dunes roughly southeast of the shoreline and beach berm, and they abut the steep slopes of the valley wall on their far eastern end (Figure 3). The dunes have also been altered by the pounding of winter storm surge, and 


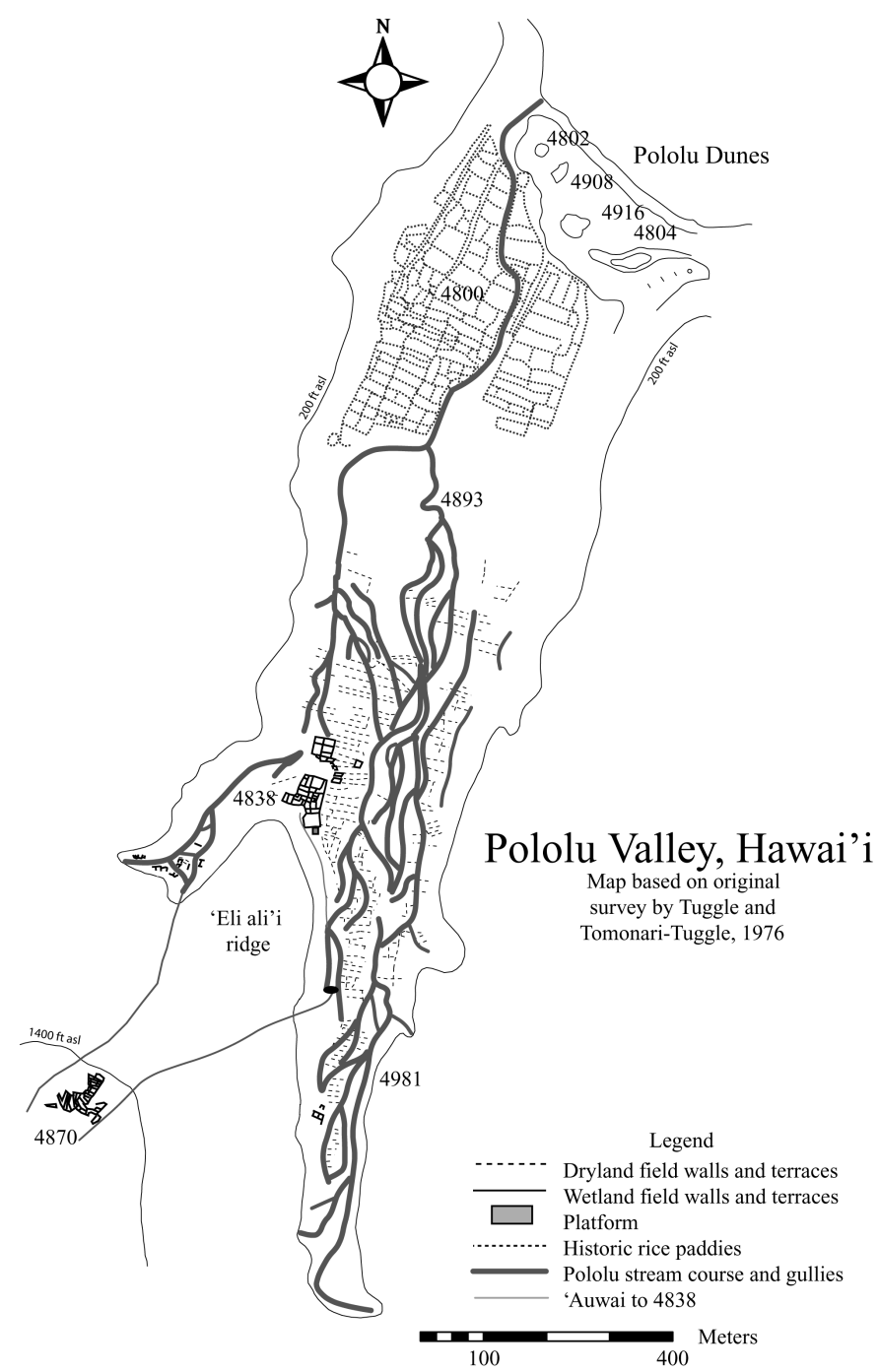

Figure 2 Map of Pololu Valley showing major sites and features. Redrafted from original (Tuggle and Tomonari-Tuggle 1976).

this has caused erosion on the northern slopes and the deposition of large numbers of waterworn boulders and cobbles on the beach. Tsunami waves have also probably impacted the dunes, although it is unknown if they have swept across the entire surface. Ironwood trees (Casuarina sp.) were planted on the dunes' slopes and peaks in the 1950s to retard erosion.

Ellis's visit to Pololu in 1823 recorded the dunes as the primary area of residence for the valley inhabitants (Ellis 1969:273), although Euroamerican and Asian artifacts from the historic period have been found at other sites in the valley. The constant deposition of sand in this area created ideal conditions for the burial and preservation of archaeological materials. Tuggle's investigations in 1972 focused on areas of the dunes that had visible eroding cultural deposits, and also the higher parts of the dunes that retain local place names. Tuggle excavated approximately 15 units, and some of these were aggregated into "sites." Sites 4802, 4908, and 4916 contained the deepest prehistoric 


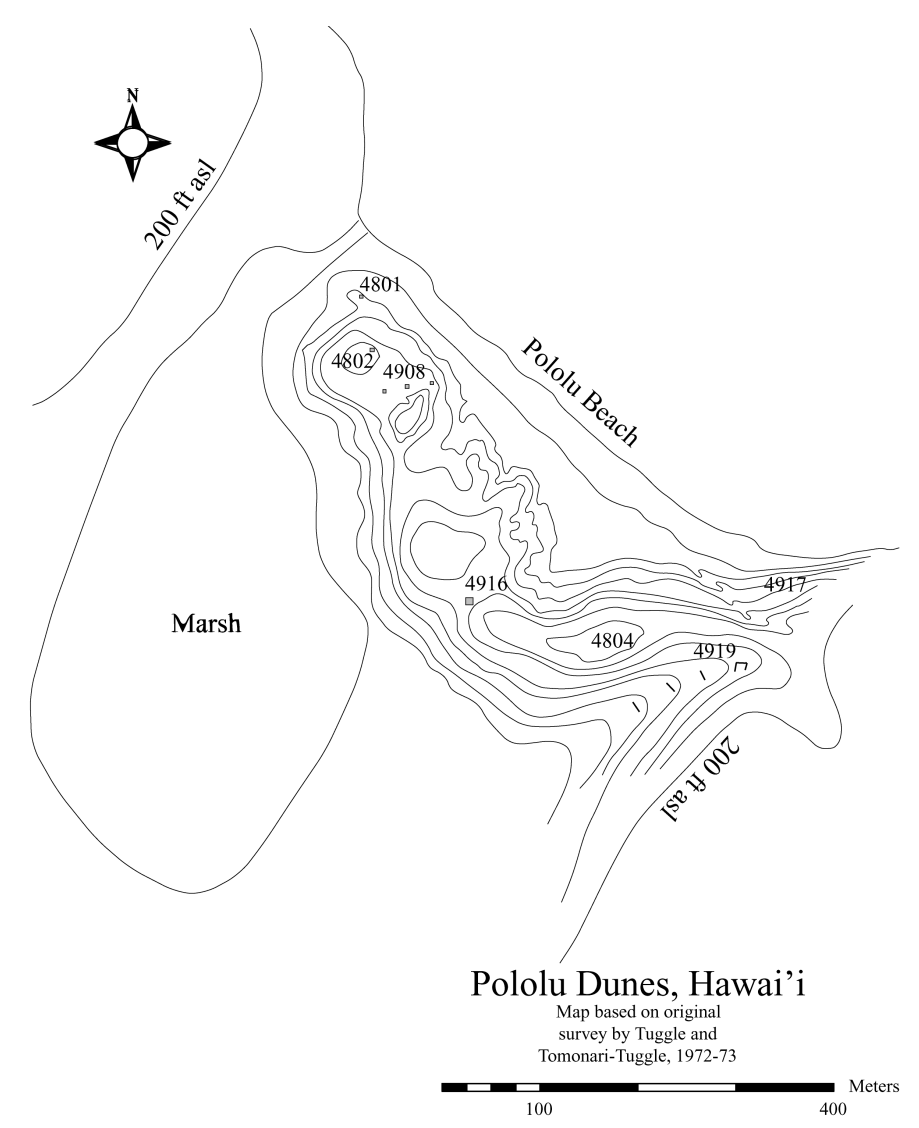

Figure 3 Map of Pololu Dunes with excavation units and sites indicated. Redrafted from original by Tuggle and Tomonari-Tuggle, 1972-1974. Topographic contour on dunes 10 feet; highest point of dunes is approximately 50 feet.

deposits on the dunes, with numerous occupation layers, features, and sequences of stone pavements. Site 4804 was thought to be the location of Ho 'olonopahu heiau (Thrum 1906), although no visible remains of the structure existed on the surface, and no excavations were conducted. Other excavations revealed historic deposits, stone pavements, packed sand occupation surfaces, firepits, eroding middens, and stone-faced terraces (sites 4801, 4917, 4919). Although Tuggle was not able to correlate the stratigraphic relationships between the deposits encountered in the various test excavations, stratified layers that were interpreted to have derived from cultural occupations were encountered in nearly every unit. The organic content of these deposits was limited to small amounts of kukui nutshell (Aleurites moluccana), some charred plants and woods, marine shell, mammal and fish bone, and larger amounts of lithic debris. The majority of the latter were fragments of volcanic glass, cobble choppers, and stone adze fragments (Tuggle 1976:18). Volcanic-glass-derived dates suggested a calendar date of AD 1400 to the historic period for occupation on the dunes.

Our interest in procuring a suite of more accurate dates for Pololu Dunes focused on sites 4802, 4908, and 4916, which had the deepest stratified deposits. The first, 4802, is located on the west end of the dune, and atop a high knoll that is known as the historic house site of Pu 'u Ali 'i. Excavation at the site consisted of a single $1.5-\mathrm{m}^{2}$ unit placed atop the hill. The deposits contained 2 horizons of stone paving (Features 1 and 2), the deepest at $220 \mathrm{~cm}$ below the surface. The paved layers are 
described in the field notes as mixtures of waterworn cobbles and pebbles, charcoal, lithics, and other cultural items. Samples of charcoal obtained from Feature 2 were submitted in 2006 to the wood identification laboratory at International Archaeological Research Institute Inc. (IARII) in Honolulu, Hawai' $i$. The identified specimens included 'lei (Osteomeles anthyllidifolia), hau (Hibiscus tiliaceus), lama (Diospyros sandwicensis), and koa (Acacia koa). The 'ulei, a native shrub, is perhaps the shortest-lived of this assemblage. Ethnographic accounts describe this plant as a raw material for the handles of nets, or as flower garlands ('ulei) (Abbott 1992). A sample of this charcoal was submitted for AMS dating, providing a date of $398 \pm 38$ BP (WK-19315). With calibration, the calendar age for this sample is in the range of cal AD 1435-1632 (2 $\sigma)$ (Table 1, Figure 4).

Table 1 Standard radiometric and AMS results from Pololu Valley, 1980-2008.

\begin{tabular}{|c|c|c|c|c|c|c|c|}
\hline ID & Location & Analysis & $\begin{array}{l}{ }^{13} \mathrm{C} /{ }^{12} \mathrm{C} \\
\text { ratio }\end{array}$ & $\mathrm{CRA}^{\mathrm{a}}$ & \pm & Calibrated date range ${ }^{b}$ & Taxa \\
\hline WK-19311 & 4916 & AMS & -23.9 & 781 & 38 & $\begin{array}{l}\text { cal AD 1223-1270 }(1 \sigma) \\
\text { cal AD 1184-1284 }(2 \sigma)\end{array}$ & cf. fern caudex \\
\hline WK-19310 & 4916 & ${ }^{14} \mathrm{C}$ & -23.8 & 696 & 35 & $\begin{array}{l}\text { cal AD } 1277-1380(1 \sigma) \\
\text { cal AD } 1258-1390(2 \sigma)\end{array}$ & cf. fern caudex \\
\hline WK-19312 & 4916 & AMS & -23.9 & 568 & 38 & $\begin{array}{l}\text { cal AD 1316-1415 (1 } \sigma) \\
\text { cal AD 1298-1430 }(2 \sigma)\end{array}$ & $\begin{array}{l}\text { kukui nutshell } \\
\text { (Aleurites moluc- } \\
\text { cana) }\end{array}$ \\
\hline WK-19313 & 4908 & AMS & -23.7 & 463 & 31 & 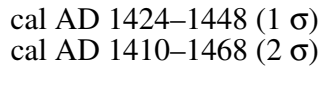 & $\begin{array}{l}\text { kukui nutshell } \\
\text { (Aleurites moluc- } \\
\text { cana) }\end{array}$ \\
\hline WK-19315 & 4802 & AMS & -25.4 & 398 & 38 & $\begin{array}{l}\text { cal AD } 1443-1616(1 \sigma) \\
\text { cal AD } 1435-1632(2 \sigma)\end{array}$ & $\begin{array}{l}\text { 'ulei }(\text { Osteomeles } \\
\text { anthyllidifolia })\end{array}$ \\
\hline WK-19314 & 4908 & AMS & -21.6 & 188 & 33 & $\begin{array}{l}\text { cal AD 1664-1952 (1 } \sigma) \\
\text { cal AD 1648-1954 }(2 \sigma)\end{array}$ & $\begin{array}{l}\text { kukui nutshell } \\
\text { (Aleurites moluc- } \\
\text { cana) }\end{array}$ \\
\hline Beta-233035 & 4838 & ${ }^{14} \mathrm{C}$ & -10 & 550 & 60 & $\begin{array}{l}\text { cal AD 1316-1355 } \\
\text { and } 1388-1430(1 \sigma) \\
\text { cal AD } 1295-1444(2 \sigma)\end{array}$ & $\begin{array}{l}\text { 'akoko (Chamae- } \\
\text { syce sp.) }\end{array}$ \\
\hline Beta-233038 & 4838 & AMS & -26.9 & 390 & 40 & $\begin{array}{l}\text { cal AD 1445-1618 }(1 \sigma) \\
\text { cal AD } 1436-1634(2 \sigma)\end{array}$ & $\begin{array}{l}\text { 'akoko (Chamae- } \\
\text { syce } \mathrm{sp} .)\end{array}$ \\
\hline Beta-233037 & 4838 & AMS & -11.7 & 170 & 40 & $\begin{array}{l}\text { cal AD 1665-1952 }(1 \sigma) \\
\text { cal AD 1655-1954 }(2 \sigma)\end{array}$ & $\begin{array}{l}\text { 'akoko (Chamae- } \\
\text { syce sp.) }\end{array}$ \\
\hline Beta-233036 & 4838 & AMS & -26.9 & 100 & 40 & $\begin{array}{l}\text { cal AD 1694-1918 (1 } \sigma) \\
\text { cal AD 1680-1939 }(2 \sigma)\end{array}$ & $\begin{array}{l}\text { kukui wood (Aleu- } \\
\text { rites moluccana) }\end{array}$ \\
\hline Beta-233034 & 4838 & AMS & -25.7 & 80 & 40 & $\begin{array}{l}\text { cal AD 1696-1917 (1 } \sigma) \\
\text { cal AD 1681-1937 }(2 \sigma)\end{array}$ & $\begin{array}{l}\text { kukui nutshell } \\
\text { (Aleurites moluc- } \\
\text { cana) }\end{array}$ \\
\hline N-2180 & 4981 & ${ }^{14} \mathrm{C}$ & unknown & 450 & 80 & $\begin{array}{l}\text { cal AD 1402-1620 }(1 \sigma) \\
\text { cal AD 1316-1642 }(2 \sigma)\end{array}$ & unknown charcoal \\
\hline N-2181 & 4893 & ${ }^{14} \mathrm{C}$ & unknown & 270 & 95 & $\begin{array}{l}\text { cal AD 1480-1952 }(1 \sigma) \\
\text { cal AD 1444-1954 }(2 \sigma)\end{array}$ & unknown charcoal \\
\hline N-2179 & 4870 & ${ }^{14} \mathrm{C}$ & unknown & 260 & 80 & $\begin{array}{l}\text { cal AD 1494-1952 }(1 \sigma) \\
\text { cal AD 1449-1954 }(2 \sigma)\end{array}$ & unknown charcoal \\
\hline N-2182 & 4893 & ${ }^{14} \mathrm{C}$ & unknown & 260 & 80 & $\begin{array}{l}\text { cal AD 1494-1952 }(1 \sigma) \\
\text { cal AD 1449-1954 }(2 \sigma)\end{array}$ & unknown charcoal \\
\hline
\end{tabular}

${ }^{\mathrm{a}} \mathrm{CRA}=$ conventional radiocarbon age.

${ }^{\mathrm{b}}$ Calibrated with OxCal v 4.05 (Bronk Ramsey 1995, 2001, 2008), using the IntCal04 atmospheric curve data (Reimer et al. 2004).

Site 4908 was described as a small hilltop just east of $\mathrm{Pu}^{\text {' } u}$ Ali' ${ }^{\text {'i }}$. Three test pits were placed in the vicinity of this site, and they were aligned along an axis that ran from the hilltop to the base of the 


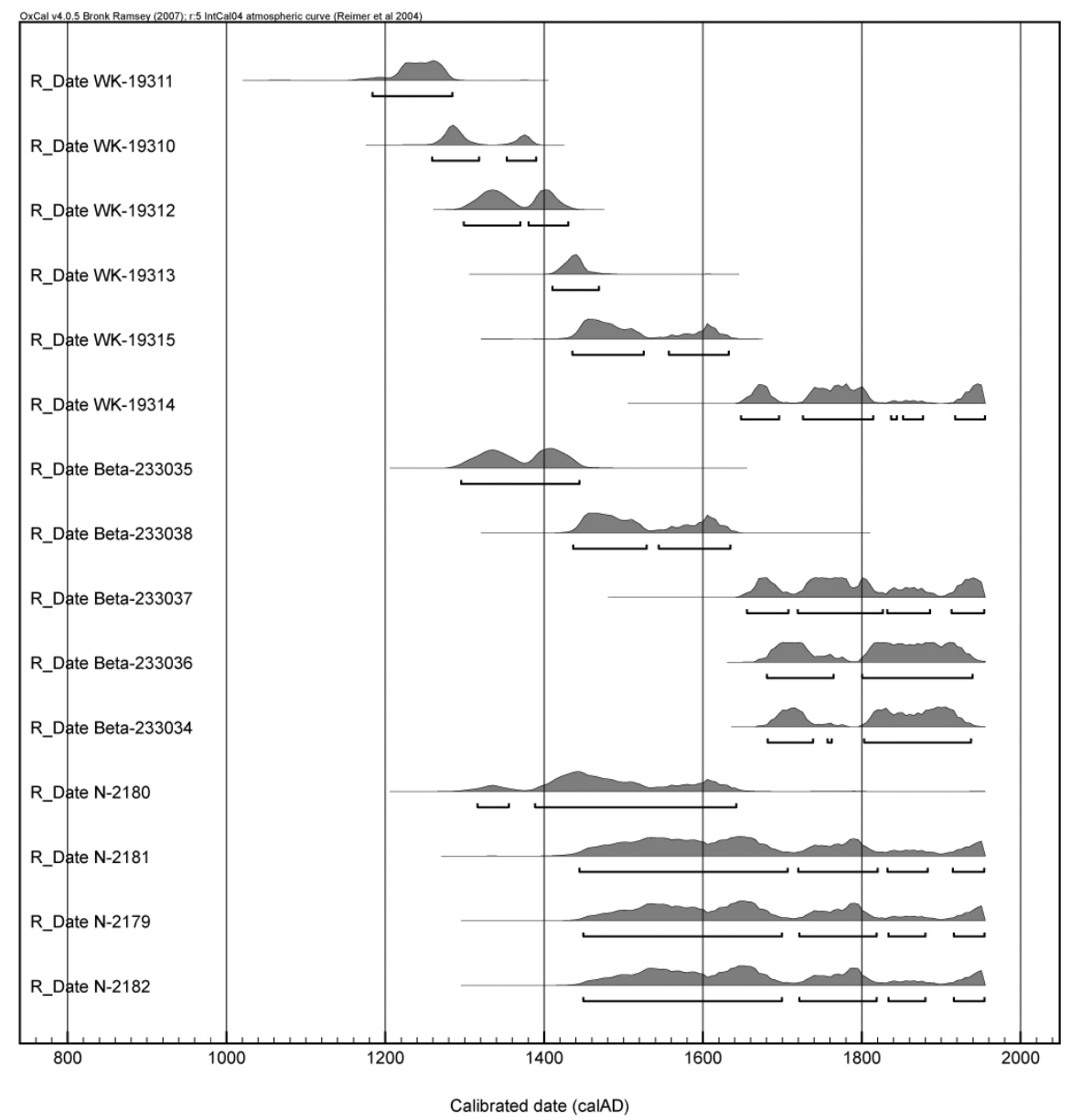

Figure 4 Calibrated dates from Pololu Valley. N-series dates were recalibrated using the original determinations published by Tuggle and Tomonari-Tuggle (1980).

dunes on the northern side. Tuggle and his crew also excavated laterally into the eroding bank of the hilltop, producing a profile called Face 1. This excavation revealed a deep stratified deposit for the area that was layered with stone pavements and cultural deposits. The notes from the excavation record the presence of animal bones and volcanic glass flakes within the paved layers, indicating their probable use as occupation surfaces. The deepest paved layer, Strat IV, lay at approximately $170 \mathrm{~cm}$ below the surface. A sample of kukui nutshells, which were mixed in with the charcoal and cultural deposits in this layer, were submitted for AMS dating. Kukui nuts, which grow anew each season, and trees of which were introduced to the islands by Polynesians, are well suited to precision dating in tropical archaeological contexts. In ancient Hawai' $i$, kukui nuts were regularly used for their oil, and retrieved from their preferred habitats in the valley interior to be used in lamps and as food seasoning. The AMS result of $463 \pm 31 \mathrm{BP}$ (WK-19313) for the kukui nutshells provides a calendar age of cal AD 1410-1468 (at $2 \sigma$ ) for Strat IV. A second sample of kukui nutshells was collected from a feature that was identified as a fire hearth. This sample was in Strat III of Face 1 of 4908, and located approximately $133 \mathrm{~cm}$ below the surface. This sample was also submitted for AMS dating, and resulted in the date of $188 \pm 33$ (WK-19314). With calibration, this later feature dates to cal AD 1648-1954 (2 $\sigma)$. 
Site 4916 was the scene of the largest excavation on the dunes. The site was near the knoll known as $\mathrm{Pu}$ 'u Koa, although the actual excavations were to the southeast of the hill crest, and in a lower area that was sheltered from the wind and on the valley side of the dunes. Five $150-\mathrm{cm}^{2}$ units (units M-10, M-12, N-11, O-10, and O-12) were excavated in this area, and all reached over $1 \mathrm{~m}$ in depth. The units were arranged in a checker-board pattern, with unexcavated units in the grid separating each excavated unit. This strategy generated multiple stratigraphic profiles, which allowed for the assessment of the spatial relationships of the deposits. Samples of charcoal from a fire hearth that was located approximately $24 \mathrm{~cm}$ below the surface were identified as cf. fern caudex (the root or stalk of an unidentified fern); alahe' $e$ (Canthium odoratum), a native tree; and cf. guava (possibly Psidium guavajava). The latter of these plants is an historic introduction to the Hawaiian Islands. Although undated, these charcoal samples suggest a historic-period age for the upper $24 \mathrm{~cm}$ of 4916 .

The deeper deposits are undoubtedly prehistoric, and of considerable age. A sample of kukui nutshell from Strat IV of unit O-10 was submitted for AMS dating. This layer lay at approximately 40 $\mathrm{cm}$ below the surface, and extended across the site to appear in the other units (Figure 5). Although the notes do not indicate that this was a paved living surface, the deposit contained charcoal, lithics, and other cultural debris. The resulting AMS date of $568 \pm 38$ (WK-19312) calibrates to cal AD $1298-1430$ (at $2 \sigma$ ). At the deepest depths of the site, 2 features contained abundant cultural materials within the context of adjacent fire hearths. Features 4 and 6 are shown most clearly in the profiles of unit M-10 (Figure 4). Each of these features was located at approximately $99 \mathrm{~cm}$ below the surface. Both were described in the original notes as hearth features, with thick lenses of charcoal, waterworn stones, lithics, and food debris. A large sample of charcoal with distinct fibrous strands was removed from the remains of Feature 4 and identified as cf. fern caudex. Most likely this plant is one of the larger native ferns, possibly hapu'u (Cibotium chamissoi). This sample was submitted for standard ${ }^{14} \mathrm{C}$ dating and returned a result of $696 \pm 35 \mathrm{BP}$ (WK-19310), providing a calendar age of cal AD 1258-1390 (at $2 \sigma$ ). Similarly, the adjacent Feature 6 also contained charcoal fragments that were identified as cf. fern caudex. The resulting date of $781 \pm 38$ (WK-19311) calibrates to cal AD 1184-1284 (also at $2 \sigma$ ).

The generation of this new sequence of dates for Pololu Dunes indicates that initial occupation is reliably dated to $200 \mathrm{yr}$ earlier than had been determined by the 1972-1974 analyses. The dates also are consistent with their stratigraphic placement within these sites, especially for 4916 and 4908. These dates are also more securely tied to discrete archaeological events, such as the construction and use of fire hearths and occupation surfaces established on stone pavements, and they were obtained from short-lived native species. The earliest dates are also from the leeward side of the dune, which is the more sheltered and inland. Occupation in this area indicates a presence on the site about AD 1200, with associated habitation debris. However, there is no indication at this period for the creation of stone-faced house platforms or pavements. These appear to have been constructed later, perhaps $\mathrm{AD} 1400$ at the earliest, and were located on the hilltops at the crest of the dunes. Most of these have historic deposits in their uppermost layers, indicating that many of these habitations were in use, perhaps continuously, from the 15 th to the 19 th centuries.

\section{Redating Site 4838}

The second area of interest for determining the chronology of Pololu is site 4838, located approximately $2.5 \mathrm{~km}$ inland, and near the valley's midpoint (Figure 2). This complex consists of an extensive network of stone-faced terraces and walls that were used for agricultural production and habitation (Figure 6). Unlike the dryland terraces that extend across the flat valley floor, the terraces of site 4838 are taller and more massive, and appear to be associated with a central corridor. Tuggle's research in 1972 and 1973 included 23 test excavations in the walls and terraces of the site. The pur- 
Pololu Dunes

Profile of unit M-10, site 4916

Redrafted from original produced

by P. Beggarly, 1974

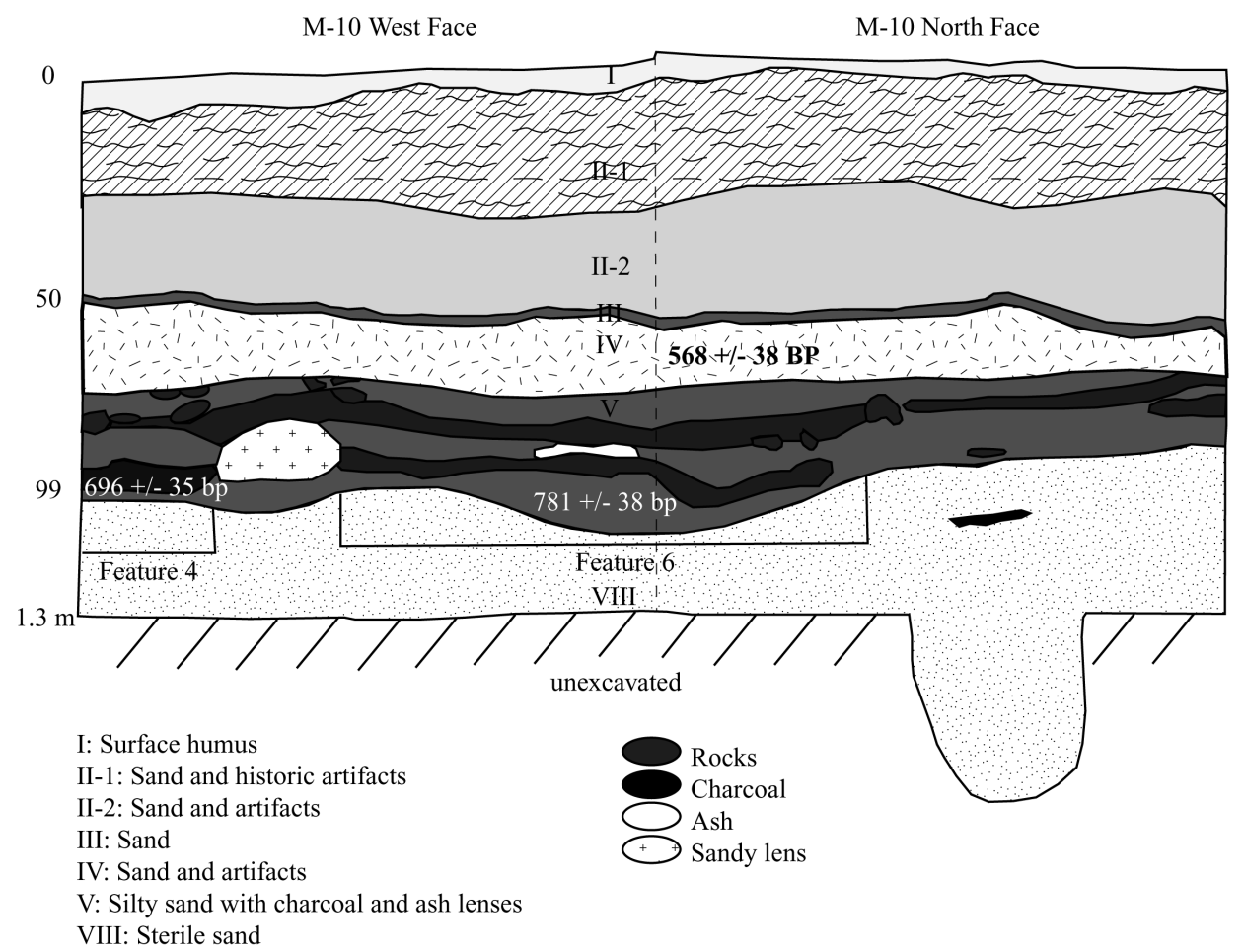

Figure 5 Northern and western faces of unit M-10, site 4916 of Pololu Dunes. ${ }^{14} \mathrm{C}$ determinations and their contexts indicated in diagram. Profile redrafted from original by P Beggarly (1974).

pose of these excavations was to assess the stratigraphy of the terraces and determine the relationship between the dryland field boundaries and irrigated features, and also determine the construction sequence for the site. Excavations were also placed between terraces and across walls in the hopes of locating deposits or features that were part of earlier habitation or agricultural features. Tuggle and Tomonari-Tuggle (1980) suggest that based on the excavations and associated volcanic glass and ${ }^{14} \mathrm{C}$ dates, the dryland field system that cascades down the valley floor had been constructed prior to site 4838, perhaps during the 16th century. They also hypothesize that the predominance of dryland cultivation in Pololu is due to geological and hydrological conditions.

This latter hypothesis has been upheld by recent geological analyses, which indicate that Pololu Stream is intermittent, and water flow sinks below the streambed and emerges at the coastline where it forms an impounded marsh (Presley 1999). The presence of deeply cut gullies indicates that water flow in Pololu is typically torrential, and can easily damage or destroy any construction related to irrigation. These conditions would have made dryland cultivation the most suitable method for Pololu farmers for most of the valley's history. Moreover, recent analyses of alluvial deposits in Pololu (Palmer et al. 2008) document a relatively nutrient-rich sedimentary matrix for valley floor, and this deposit would have sustained vibrant growth for dryland farming. The combination of higher rainfall and the periodic renewal of these soils with alluvial deposition clearly fostered the 


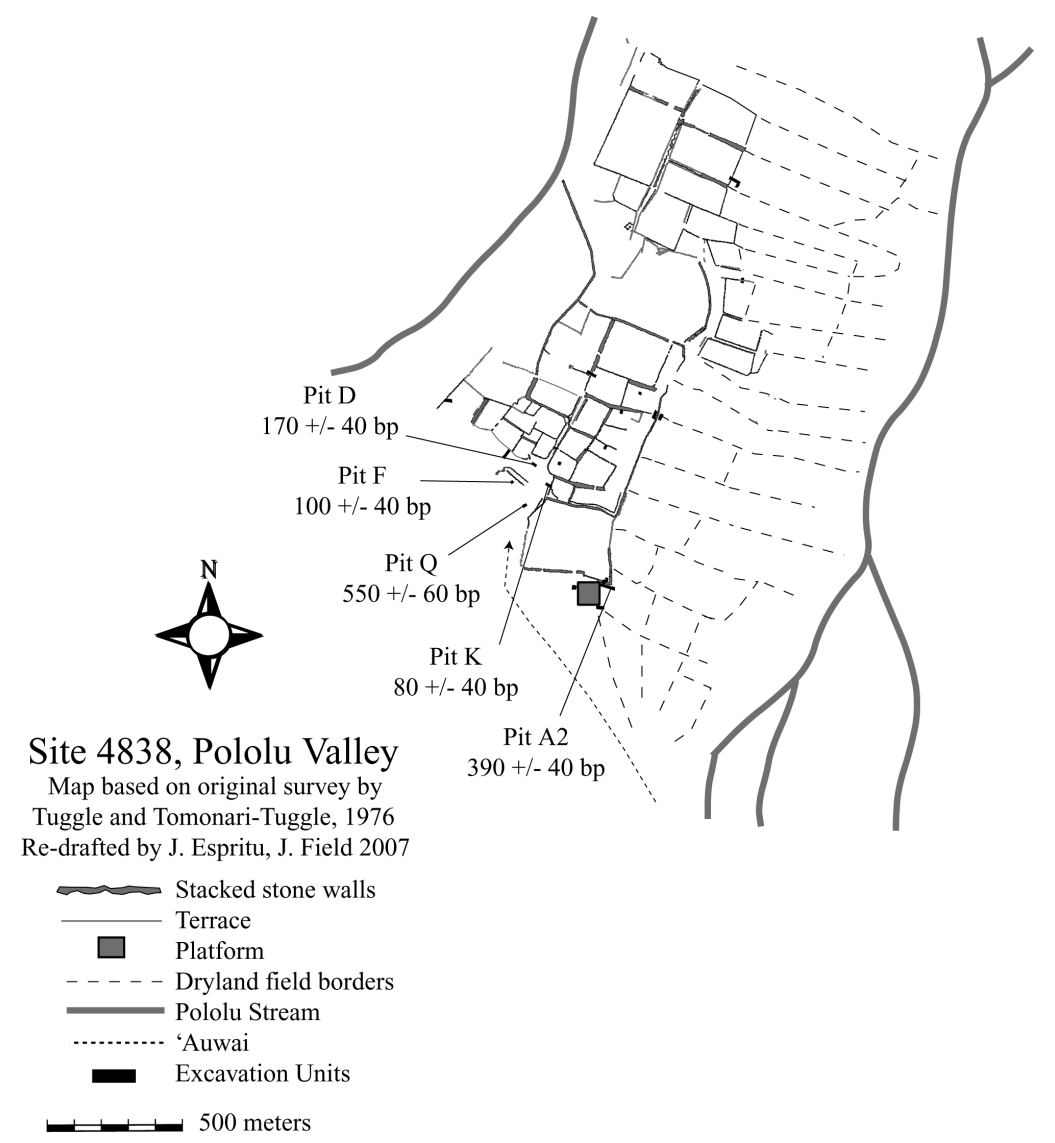

Figure 6 Map of site 4839, Pololu Valley. Redrafted from original by Tuggle and TomonariTuggle $(1976,1980)$.

strategy of dryland cultivation, as dryland terraces cover an area of more than 28 ha in the valley (Figure 2). The instances of irrigation in the valley are more limited (such as site 4838 and 4870), and appear to have been constructed to take advantage of springs or perched water tables in the uplands, or were constructed during periods of higher rainfall and streamflow.

Tuggle's analysis of the topographic situation of 4838 , as well as the presence of paved surfaces and an interior irrigation canal led to the formulation of the following sequence: 1) The southernmost (inland) section of 4838 was constructed first and water was brought in via a canal from a waterfall source that lies $500 \mathrm{~m}$ up the valley. This water was distributed to terraces in the southern section of 4838 via the central irrigation canal. 2) Some dry terraces were converted to irrigated terraces in the central and northern portions of the complex. 3) At some later point in time, the irrigation canal was abandoned and terraces in the southern part of the complex were converted to habitation use. Other terraces also show a period of abandonment followed by a reinstallation of irrigated cultivation.

Although Tuggle's research and excavations generated a detailed assessment of the relative chronology of agricultural development at 4838 (and throughout Pololu Valley itself), the reliance on volcanic hydration dating severely hinders any additional refinement of the sequence. Our research bridges that gap with 5 samples of wood charcoal and nutshell. Again, using Tuggle's notes and 
manuscripts as a guide, the samples were removed from the curated collection and submitted for identification to the Wood ID laboratory at IARII. Care was taken to sample from well-described archaeological contexts, such as layers of clayey deposits buried within the terraces that are probably the result of pondfield cultivation. Deposits that may have been part of the 'auwai (irrigation ditch), as well as features with abundant cultural materials and artifacts, were also sampled.

The earliest date for site 4838 was obtained from deposits in Pit Q, which is located on Terrace 431 and above the place Tuggle thought the irrigation canal might have entered the site (Figure 6). The deposits in Pit Q consisted of 4 strata of colluvium, with historic artifacts present in the upper 2 strata (I and II). A fire hearth with abundant charcoal was present in Strat III, and Strat IV below it contained abundant obsidian, basalt tools, and animal bones and teeth. This, then, is not an agricultural deposit, but most likely a habitation area. A sample of 'akoko (Chamaesyce sp.) wood charcoal (Beta-233035) was obtained from this deposit at a depth of approximately $100 \mathrm{~cm}$ below surface and dated using standard ${ }^{14} \mathrm{C}$ dating, resulting in a calculation of $550 \pm 60 \mathrm{BP}$. With calibration, this result gives an age of cal AD 1295-1444 (at $2 \sigma$ ). 'Akoko is a shrub that was often used for firewood in Hawai' $i$. These dates suggest the early use of the high-ground at the back of the site for habitation. Tuggle (1976) and Tomonari-Tuggle (n.d.) had suggested this area was used for habitation as the topography afforded relative safety from flash floods.

In addition to the deposits in Pit Q, early occupation at the site is indicated by deposits on the floor of Pololu Valley. Pit A2 was placed in close proximity to a large stone platform located in the southernmost portion of the 4838 complex (Tuggle and Tomonari-Tuggle 1980:305) (Figure 6). This platform was in direct association with dryland field walls, and Pit A2 was placed to test the age of these deposits, and also test the age of a large wall (\#429), which Tuggle believed to be of late-historic age and perhaps related to corralling stock animals at the site. Three strata were identified below the wall; the 2 uppermost strata (I and II) consisted of the rubble and cobbles that made up wall \#429. Below this in Strat III, a series of intersecting pits were encountered and these appeared to have cultural deposits (obsidian and basalt) that had been raked out and replaced with gravel, silt, sand, and cultural debris. Tuggle surmised that this configuration may have resulted through the construction and later filling of an imu (an earth oven used for roasting meats and vegetables), with the base of the iти used as the foundation for the wall. Charcoal fragments of 3 native plants 'akoko (Chamaesyce sp.), lama (Diospyros sandwicensis), and perhaps hame (cf. Antidesma sp.) were taken from the base of the pit feature in Strat III, at approximately $1.01 \mathrm{~m}$ below surface. The sample of 'akoko was submitted for AMS dating (Beta-233038), resulting in the determination of $390 \pm 40 \mathrm{BP}$, which calibrates to cal AD 1436-1634 (at $2 \sigma$ ). This date is associated with the construction and use of the imu, and therefore indicates that occupation of this part of the valley occurred about AD 1500. The close proximity of these deposits to the dryland field walls suggest a similar age for the establishment of dryland cultivation in this part of the valley.

Close by to Pit Q, Pit F was excavated across western edge of Terrace 431. Although topographically similar to the context for Pit Q, the deposits in this unit were disturbed and did not retain as much stratigraphic cohesion. The uppermost strata (I and II) contained charcoal and historic artifacts. Two samples of wood charcoal were identified from this deposit: lama (Diospyros sandwicensis) and kukui (Aleurites moluccana). The sample of kukui wood charcoal was retrieved from the bottom of Strat II and submitted for AMS dating, resulting in a recent conventional age, $100 \pm 40 \mathrm{BP}$ (Beta-233036). Calibration suggests an age range of cal AD 1680-1939 (2 $\sigma)$, with intercepts at cal AD 1680-1764 (30.7\%) and 1800-1939 (64.7\%) (Figure 4). The later centuries of this range are the more likely, and also reflect what is known for the late prehistoric and historic use of the area based on the other materials contained in the strata. 
The best context for dating irrigated agriculture at site 4838 is present in the materials from Pit D. This excavation was a trench that crossed through the center of terrace 430 , which was interpreted as an agricultural feature. If Tuggle's analysis of the irrigation system is correct, this terrace is the first that could have been irrigated, as it is located at the mouth of the irrigation canal where it enters the site from the south. According to the excavation notes, the deposits consisted of layers of tanbrown sandy clays with ferrous banding layers. Layer II was described as a layer of gray-brown clay, and Layer III below it was described as a band of brown granular clay that was heavily stained with ferrous deposits. This description is similar to observations of pondfield soils described elsewhere (Kirch 1977:254). Three charcoal samples were identified from the deposit, consisting of 'ōhia 'āi (Syzigium sp.), 'ōhi'a lehua (Metrosideros polymorpha), and 'akoko (Chamaesyce sp.). The latter 2 plants are native to Hawai' $i$. The sample of 'akoko wood charcoal (Beta-233037) recovered from Layer III was submitted for AMS dating. The resulting AMS date of $170 \pm 40 \mathrm{BP}$ was calibrated and produced multiple intercepts between the calendar age range of cal AD 1655-1954 (2 $\sigma)$. The highest peak, cal AD 1655-1826 (64.9\%) (Figure 4), is the most likely of the determinations, as Pololu is known to have been largely abandoned by all but a few families by the early 1900s.

Pit $\mathrm{K}$ represents the second attempt to date and discern the presence of irrigation at site 4838 . This unit was placed across the surface of terrace 430 , and along a north-south running wall that may have been the location for the 'auwai, the channel that directed the water into the system. The stratigraphic profile of Pit $\mathrm{K}$ indicates the presence of a surface layer of humus on the terrace, below which lay loose, gray silty clay (Strat II). A pebbly orange-gray clay lies below this (Strat IIIa), followed by compacted gray silt deposits (Strats IVa and IVb). Although this description is similar to conditions described for irrigated agriculture, the deposits are not clearly pondfield soils. It is possible, as Tuggle surmised, that these deposits alternated between pondfield and 'auwai, and this may explain the presence of the pebbly layer in Strat IIIa. A sample of kukui nutshell (Beta-233034) was retrieved from this level, and the resulting AMS date of $80 \pm 40 \mathrm{BP}$ suggests a fairly modern context. Calibration suggests calendar ages of cal AD 1681-1937, with the bulk of the age occurring between cal AD 1802-1937 (68.3\%) (Figure 4). This suggests a very late age for the pondfield deposits in Pit K.

In summary, 2 contexts from the southern portion of the site indicate that this high ground was used for occupation from the 13th century onwards. Whether 4838 was used for wetland cultivation during this early period is unknown. However, the buried imu deposit from Pit A2 indicates that the valley floor was used for habitation by the 15th century AD, and the proximity of the ancient platform to the dryland field walls mapped by Tuggle further suggests a linkage between early inland occupations and dryland cultivation. The excavations at 4838 show clear evidence of pondfield agriculture on some of the terraces, and the 'auwai that entered from the south appears to be the most likely water source. The samples from terraces in this area suggest the earliest use of irrigation between cal AD 1650 and 1850, with later use up to the historic era. Layering of flood deposits also support the interpretation of flooding at the site, perhaps followed by periods of when the irrigation system was not in use.

\section{Redating Other Agricultural Complexes in Pololu Valley}

There are several agricultural complexes within Pololu Valley previously documented and dated by Tuggle and Tomonari-Tuggle (1980) and Tomonari-Tuggle (1981), and these sites provide further chronological information. Immediately inland of the Pololu Dunes is a large marsh area, designated as site 4800 (Tomonari-Tuggle 1981:22). Within the marsh are a series of 125+ irrigated terraces 
(see Figure 2) covering at least 6 ha, the largest single complex in the valley. The configuration of these terraces and documentary evidence confirm their original use for kalo cultivation through the middle 19th century. Sometime after 1870, rice agriculture was introduced to the valley, ultimately supplanting kalo, and this practice continued until 1926 when rice farming was abandoned in Pololu. There are no ${ }^{14} \mathrm{C}$ dates on the construction of the terraces at site 4800 , and at present we hypothesize that portions of the marsh were likely converted to kalo cultivation soon after human occupation on the dunes in the 13th or 14th century.

Site 4893 is a dryland agricultural complex consisting of buried terraces located $\sim 200 \mathrm{~m}$ inland from the marsh complex (Figure 2). Although the shifting courses of Pololu Stream have partially destroyed the terrace deposits, remnants of the fields remain clearly identifiable across the entire distance of the defined site area. Tuggle and Tomonari-Tuggle's investigations defined 3 agricultural strata (generally 10-20 cm thick) interspersed between alluvial deposits of varying thicknesses (Tuggle and Tomonari-Tuggle 1980:307). Test excavations F and I indicate that the lowest agricultural stratum is approximately $2.5 \mathrm{~m}$ below the present surface. Tuggle and Tomonari-Tuggle report $2{ }^{14} \mathrm{C}$ determinations from these excavations (N-2181: $\left.270 \pm 95 \mathrm{BP} ; \mathrm{N}-2182: 260 \pm 80 \mathrm{BP}\right)$, but both are from unknown stratigraphic contexts and lack data pertaining to ${ }^{13} \mathrm{C} /{ }^{12} \mathrm{C}$ ratios and identified taxa. Calibration of the N-2181 date resulted in multiple calibrated intercepts between cal AD 1444$1954(2 \sigma)$, with the bulk of the determinations falling between cal AD 1444-1820 (83.9\%) (Figure 4). Similarly, the N-2182 determination ranged from cal AD 1449-1954, with the highest probability falling at the cal AD 1449-1818 (83.4\%) range. Given the transition to rice farming in the 19th century and the abandonment of the valley in the 20th century, the 15th-17th centuries of these ranges are the most likely temporal designations for the use of this complex for dryland agriculture.

The earliest date for the interior of Pololu Valley previously reported by Tuggle and TomonariTuggle comes from site 4981 . This is the basalt adze quarry site, with much of the quarry materials distributed on the surface and stratified deposits exposed by the adjacent Pololu streambed (Figure 2). Excavations at the quarry revealed agricultural deposits and habitation features interbedded with alluvial material. The date for this site comes from one of the agricultural deposits and has a conventional determination of $450 \pm 80 \mathrm{BP}(\mathrm{N}-2180)$. Calibration of this determination produces an age range of cal AD 1316-1642 (2 $\sigma)$. Although this range is broad, it is likely that this buried dryland terrace complex was built before the 17 th century and possibly as early as the 15 th to 16 th century.

Lastly, site 4870 is an agricultural and habitation complex located on the brow of the 'Eli ali'i ridge overlooking Pololu Valley. This site is located approximately $450 \mathrm{~m}$ above the valley floor, and is directly above site 4838 (Figure 2). Although it is outside of the valley proper, its agricultural components are spring-fed, and contribute their water to the Pololu drainage system. The site consists of 46 wet and dry agricultural terraces, and at least 1 platform living area. Excavations into a platform area at the head of the site produced evidence of habitation, including fireplaces and earth ovens. A conventional date of $260 \pm 80 \mathrm{BP}(\mathrm{N}-2179)$ was determined from charcoal samples from these deposits, with a calibrated range of cal AD 1449-1954 (2 $\sigma$ ) (Tuggle 1976; Tuggle and TomonariTuggle 1980). Multiple intercepts with this calibration suggest a higher probability for the date to range between cal AD 1449-1818 (84.3\%) (Figure 4). This is the first dating of an upland ridge top agricultural site in windward Kohala. The use of upland springs for agriculture is an innovation in Kohala, identified in oral traditions (Cachola-Abad 2000; Handy and Handy 1972), and documented on early agricultural survey maps, as well as by more recent archaeological surveys (McCoy and Graves 2007). This farming practice may have been widespread across many of the ridges that separated the smaller gulches in Kohala. 


\section{SUMMARY OF POLOLU SETTLEMENT AND AGRICULTURAL CHRONOLOGY}

The analysis of wood charcoal and nutshell samples using AMS and standard ${ }^{14} \mathrm{C}$ dating has produced a more accurate chronology for Pololu Valley, and also allowed for the analysis of the sequence of habitation, agricultural investment, and transitions between wetland and dryland cultivation technologies. The earliest calibrated dates indicate that the dunes that front the valley were occupied about AD 1200, and this occupation continued through the historic period. Permanent stone house platforms appeared on the dunes sometime after AD 1400. Although we do not have precise estimation for the cultivation of the marsh that lies immediately inland from the dunes, it is a probable spot for the earliest agricultural system during this early period. The system of paddies and channels that were documented for rice production in the early part of the 20th century likely have their origins in pre-existing 13th century kalo terraces. Transformations of this kind (from kalo to rice) have been documented in other parts of Hawai' $i$ during the 20th century (Earle 1978).

Settlement in the interior of the valley is indicated by 2 early dates from habitation contexts from site 4838 , and these span the 13th-15th centuries AD. This accords relatively well with the early date from the vicinity of the adze quarry (site 4981), which comes from a dryland agricultural context. Combined, these dates indicate that settlement and dryland cultivation were established in the interior parts of Pololu by the 15th century. Agricultural production appears to have expanded throughout the valley in later centuries, and was established in the lower portions that fringe the marsh by the 17th century. This portion of the valley might have been the more difficult area to cultivate, as evinced by the interbedding of alluvial and agricultural layers. These deposits reflect the periodic flooding, burial, and scouring of dryland fields along the lower extent of Pololu Stream.

Complexes 4838 and 4870 include both habitation and agricultural features. Sequences of silty clay deposits and bands of ferrous minerals indicate that some terraces were used for irrigated cultivation, but there is also evidence for the resumption of dryland cultivation in later periods. Other terraces contained deposits that suggest that dryland and wetland cultivation was practiced simultaneously at the site. Chronometric dating from what are most likely irrigated contexts at 4838 suggests their construction after the 17th century. Historic materials at both sites indicate continued occupation and the use of these complexes into the late 18th and early 19th centuries.

\section{DISCUSSION: COMPARISONS AND OBSERVATIONS ON SETTLEMENT AND AGRICUL- TURAL DEVELOPMENT IN KOHALA AND THE HAWAIIAN ISLANDS}

As a result of this study, the cultural deposits of Pololu Dunes are now the earliest and most securely dated coastal occupation in the district of Kohala. Research in the 1970s and 80s suggested that the coastal occupations of Lapakahi in leeward Kohala may date to the same period (about AD 1300) (Tuggle and Griffin 1973:55-59); however, these dates are based on the obsidian hydration method, and are unlikely to be accurate. Other calibrated dates from similar contexts in leeward Kohala indicate a much later age range for the earliest coastal occupations, between the 15th and 17th centuries (Newman 1970; O'Hare and Goodfellow 1995; Dye and Maly 2001). In general, Pololu Dunes is not out of step with the rest of the Hawaiian Islands' sequence, which indicate that the wetter portions with potential agricultural areas in the immediate vicinity were more attractive for early settlement (Kirch 1977; Kirch and McCoy 2007; McElroy 2007). If the cultivation of the marsh fringes also dates to the 12th-13th centuries, then cultivation in Pololu mirrors the timing for the earliest dryland cultivation in leeward Kohala, about AD 1200-1300 (Ladefoged et al. 2005; Ladefoged and Graves 2008). This is an interesting scenario for Hawai ${ }^{\prime} \mathrm{i}$, as it indicates that agricultural development and habitation occurred in the windward and upland leeward areas of the district before the leeward coastline was occupied. This provides a refinement for some of the earlier models for Kohala, 
which have suggested that cultivation in the uplands proceeded as an expansion from the leeward coastal settlements (Tuggle and Griffin 1973:61; Rosendahl 1994:20). Our data indicate the opposite; that windward and mauka portions of Kohala were the core, rather than the periphery, of ancient Hawaiian settlement.

The expansion of the Pololu agricultural system across space also parallels the developments in leeward Kohala to some extent. A period of expansion has been noted for the Kohala Field System during the 14th and 15th centuries, during which time dryland fields were located in several different upland areas and later subdivided (Ladefoged et al. 2008). In the 13th-15th centuries, the farmers of Pololu expanded with dryland fields into the remote portions of the valley. Although wetland fields had probably been established at the marsh's edge, the choice to employ dryland production techniques in the rest of the valley was a practical one: this method was most suited to the unique geological conditions of the valley floor. Its success is evident in the 28 ha of valley bottom that were ultimately put into dryland production. The expanse of the Pololu dryland field system and the revised chronology presented here suggests that windward Kohala was part of a district-wide transition that included the expansion of pre-existing systems and attempts to intensify production. Ladefoged and Graves' (2000) research indicates that this expansion can be linked to the influence of chiefs, who sought to increase agricultural production and exert control over larger regions.

It also appears that dryland fields were not re-rigged for irrigated cultivation until after the 17th century, and in all cases irrigation was restricted to areas where water could be effectively controlled. The prevalence of gullies, braided streams, and sinks on the valley floor provide mute evidence of the torrential nature of the hydrological system, and the evidence for irrigated cultivation appears to be limited to 2 sites: 4838 and 4870. Both of these systems take advantage of isolated streams or springs, and thus avoid the more unpredictable flow of Pololu Stream. But, even in these situations, the application of irrigated cultivation appears to have been episodic, and the presence of interbedded deposits of clays and gravels in the terraces of 4838 indicate periods during which the system was probably flooded. The use of the site for both wetland and dryland cultivation suggests that overall the agricultural productivity of Pololu Valley was dynamic.

Lastly, the redating of Pololu Valley has implications for the chronology of colonization and population expansion in the islands. Recent excavations and redating of many archaeological sites in Hawai 'i (Tuggle and Spriggs 2002; Carson 2005; Kirch and McCoy 2007; McElroy 2007) and East Polynesia (Spriggs and Anderson 1993; Anderson and Sinoto 2002) has refined the chronology for the entire region, and led to the rejection of a pre-AD 800 colonization period. Pololu Dunes provides firm support for occupation of windward coastal areas around AD 1300, and it shares many features with similarly aged sites throughout the islands. In light of a number of models that have been put forward to redefine the sequences of Hawaiian prehistory (Kirch and McCoy 2007), the contemporaneous nature of sites like Pololu is indicative of a period in which Hawaiian populations expanded into coastal areas that could support agricultural production. This was perhaps the most critical period in the archipelago, as it represents the establishment of a settled landscape that could support a thriving population, and ultimately a complex social hierarchy. Sites like Pololu are the benchmarks for models of cultural complexity and state formation that are currently under development.

\section{CONCLUSION}

Pololu Valley, located in the district of Kohala on Hawai' $i$ Island, has been the subject of a number of archaeological investigations. This research reports on the reanalysis of the chronology of Pololu using curated archaeological samples from the early 1970s. Eleven samples of identified charcoal and nutshell were removed from well-described and secure cultural contexts and submitted for AMS and 
standard ${ }^{14} \mathrm{C}$ dating. The resulting dates indicate a chronology for Pololu that spans the 12 th-19th centuries AD. The Pololu Dunes, located at the mouth of the valley, provided the earliest evidence for occupation during the 12th and 13th centuries AD. Occupation in the valley interior (site 4838) dates to the 14th and 15th centuries, and dryland cultivation throughout the valley is similarly dated to this period. The timing of this transition has a corollary in the expansion of the Kohala Field System in leeward Kohala. Cultivation of the marsh's edge may have developed about AD 1200; however, the most secure dates for irrigated cultivation date to the 17th century at the earliest. The occurrence of strata of clay, silt, and alluvium in test excavations throughout the valley suggest that irrigated cultivation was episodic, and some dryland fields were converted to wetland during wetter periods.

In sum, the archaeological research at Pololu has revealed a prehistory that was dynamic and unique. The addition of precise chronological data places Pololu Valley firmly into the earliest regional models that are being developed for Hawaiian prehistory. The analysis of pre-existing collections and new research have the potential to reveal much about Pololu's prehistory, and also link this remote valley to demographic and sociopolitical trends that were occurring in the rest of Hawai' $i$.

\section{ACKNOWLEDGMENTS}

The fieldwork that this study is based on was directed by H David Tuggle and Myra Tomonari-Tuggle; we wish to thank them for their dedication to the region and also acknowledge the quantity and quality of their work. Jo Lynn Gunness of the University of Hawai 'i, Manoa produced an extensive database of the Pololu Valley collections that has proved invaluable; we wish to acknowledge her contribution and also express our gratitude for the curation of the Pololu Valley materials. Maps and figures were based on work performed by Jason Espiritu and Patricia Beggarly. Funding for the dates was provided by NSF award \# SES-0552977.

\section{REFERENCES}

Abbott IA. 1992. La'au Hawai 'i: Traditional Hawaiian Uses of Plants. Honolulu: Bishop Museum Press. $372 \mathrm{p}$.

Allen SJ. 1991. The role of agriculture in the evolution of the pre-contact Hawaiian state. Asian Perspectives 30(1):117-32.

Anderson A, Sinoto Y. 2002. New radiocarbon ages of colonization sites in East Polynesia. Asian Perspectives 41(2):242-57.

Athens JS, Tuggle HD, Ward JV, Welch DJ. 2002. Avifaunal extinctions, vegetation change and Polynesian impacts in prehistoric Hawai'i. Archaeology in Oceania 37(2):57-78.

Bronk Ramsey C. 1995. Radiocarbon calibration and analysis of stratigraphy: the OxCal program. Radiocarbon 37(2):425-30.

Bronk Ramsey C. 2001. Development of the radiocarbon calibration program OxCal. Radiocarbon 43(2A): 355-63.

Bronk Ramsey C. 2008. Deposition models for chronological records. Quaternary Science Reviews 27(1-2): 42-60.

Burney LP, Burney DA. 2003. Charcoal stratigraphies for Kaua'i and the timing of human arrival. Pacific Science 57(2):211-26.

Cachola-Abad CK. 2000. The evolution of Hawaiian so- cio-political complexity: an analysis of Hawaiian oral traditions [PhD dissertation]. Honolulu: University of Hawaii, Mānoa.

Carson MT. 2005. A radiocarbon dating synthesis for Kaua'i. In: Graves MW, Carson MT, editors. Na Mea Kahiko O Kaua 'i: Archaeological Studies in Kaua' $i$. Special Publication 2. Honolulu: Society for Hawaiian Archaeology. p 11-32.

Coil JH. 2004. "The Beauty That Was": archaeological investigations of ancient Hawaiian agriculture and environmental change in Kahikinui, Maui $[\mathrm{PhD}$ dissertation]. Berkeley: University of California.

Cordy RH. 1981. A Study of Prehistoric Social Change: The Development of Complex Societies in the Hawaiian Islands. New York: Academic Press. 274 p.

Dye T. 1994a. Apparent ages of marine shells: implications for archaeological dating in Hawai'i. Radiocarbon 36(1):51-7.

Dye TS. 1994b. Population trends in Hawai'i before 1778. The Hawaiian Journal of History 28:1-20.

Dye T. 2000. Effects of ${ }^{14} \mathrm{C}$ sample selection in archaeology: an example from Hawai'i. Radiocarbon 42(2): 203-17.

Dye TS, Maly K. 2001. Archaeological inventory survey of the coastal portion of Kaiholena Ahupua'a, north Kohala, Hawai'i [report]. Honolulu: International Ar- 
chaeological Research Inc.

Earle TK. 1978. Economic and Social Organization of a Complex Chiefdom: The Halelea District, Kaua 'i, Hawaii. Anthropological Papers No. 63. Ann Arbor: University of Michigan Museum of Anthropology. 205 p.

Earle TK. 1980. Prehistoric irrigation in the Hawaiian Islands: an evaluation of evolutionary significance. $A r-$ chaeology in Oceania 15(1):1-27.

Ellis W. 1969. Polynesian Researches. Rutland: Charles E. Tuttle Co. $407 \mathrm{p}$.

Graves MW, Ladefoged TN. 1994. The disparity between radiocarbon and volcanic glass dates: new evidence from the island of Lānai' i, Hawai'i. Archaeology in Oceania 26(2):70-7.

Graves MW, Field J, Vallente T, Issac D. 2006. Dating the human occupation of Pololu Valley, north Kohala, Hawai' $i$ Island. Presented at the 19th Annual Society for Hawaiian Archaeology Conference. Kailua-Kona, Hawaii Island.

Handy ES, Handy EG. 1972. Native Planters in Old Hawaii: Their Life, Lore, and Environment. Honolulu: Bishop Museum Press. 641 p.

Hommon R. 1986. Social evolution in ancient Hawaii. In: Kirch PV, editor. Island Societies: Archaeological Approaches to Evolution and Transformation. Cambridge: Cambridge University Press. p 55-68.

Kirch PV. 1977. Valley agricultural systems in prehistoric Hawaii: an archaeological observation. Asian Perspectives 20(2):246-80.

Kirch PV. 1990. The evolution of sociopolitical complexity in prehistoric Hawaii: an assessment of the archaeological evidence. Journal of World Prehistory 4(3): 311-45.

Kirch PV, McCoy M. 2007. Reconfiguring the Hawaiian cultural sequence: results of re-dating the Halawa Dune Site (MO-A1-3), Moloka'i Island. Journal of the Polynesian Society 116(4):385-406.

Kirch PV, Coil J, Hartshorn AS, Jeraj M, Vitousek PM, Chadwick OA. 2005. Intensive dryland farming on the leeward slopes of Haleakala, Maui, Hawaiian Islands: archaeological, archaeobotanical, and geochemical perspectives. World Archaeology 37(2):240-58.

Ladefoged TN, Graves MW. 2000. Evolutionary theory and the historical development of dry-land agriculture in north Kohala, Hawai 'i. American Antiquity 65(3): $423-48$.

Ladefoged TN, Graves MW. 2006. The formation of Hawaiian territories. In: Lilley I, editor. Archaeology of Oceania: Australia and the Pacific Islands. New York: Blackwell Press. p 259-83.

Ladefoged TN, Graves MW, Jennings RP. 1996. Dryland agricultural expansion and intensification in Kohala, Hawai' i Island. Antiquity 70(270):861-80.

Ladefoged TN, Graves MW, McCoy MD. 2003. Archaeological evidence for agricultural development in Kohala, Island of Hawai'i. Journal of Archaeological Science 30(7):923-40.
Ladefoged TN, Lee CT, Graves MW. 2008. Modeling life expectancy and surplus production of dynamic precontact territories in leeward Kohala, Hawai' 'i. Journal of Anthropological Archaeology 27(1):93-110.

McCoy MD, Graves MW. 2007. An archaeological survey of Halawa and Makapala ahupua ' $a$, North Kohala district, Hawai'i Island [report]. Honolulu: Hawai 'i Archaeological Research Project. 67 p.

McElroy WK. 2007. The development of irrigated agriculture in Wailau Valley, Molokai 'i Island, Hawai' ${ }^{\circ}$ [PhD dissertation]. Honolulu: University of Hawaii, Mānoa.

Mulrooney M, Ladefoged TN. 2005. Hawaiian heiau and agricultural production in the Kohala Dryland Field System. Journal of the Polynesian Society 114:45-65.

Newman TS. 1970. Hawaiian fishing and farming on the Island of Hawaii in AD 1778 [report]. Honolulu: Division of State Parks, Department of Lands and Natural Resources.

O'Hare CR, Goodfellow ST. 1995. Archaeological mitigation program data recovery excavations, Site 50-1005-4015, Kahua Makai/Kahua shores coastal parcels [report]. Hilo: Paul H. Rosendahl PhD. Inc.

Palmer N, Graves MW, Ladefoged TN, Duarte TK, Chadwick O, Porder S, Vitousek P. 2008. Sources of nutrients to windward agricultural systems in pre-contact Hawai ${ }^{i} i$. Unpublished manuscript on file. Department of Biological Sciences, Stanford University.

Presley TK. 1999. The Geohydrologic Setting of Pololu Stream, Island of Hawaii, Hawaii. US Geological Survey Water Resources Investigations Report 99-4009. $22 \mathrm{p}$.

Rosendahl P. 1972. Aboriginal agriculture and residence patterns in upland Lapakahi, Island of Hawai ' $\mathrm{i}[\mathrm{PhD}$ dissertation]. Honolulu: University of Hawaii, Mānoa.

Rosendahl P. 1994. Aboriginal Hawaiian structural remains and settlement patterns in the upland agricultural zone at Lapakahi, Island of Hawai' $i$. Hawaiian Archaeology 3:14-70.

Spriggs M, Anderson A. 1993. Late colonization of East Polynesia. Antiquity 67(255):200-17.

Thrum TG. 1906. Heiau and heiau sites throughout the Hawaiian Islands. The Hawaiian Annual for 1907. p 36-48.

Tomonari-Tuggle MJ. 1981. North Kohala: Perception of a Changing Community. A Cultural Resource Study. Honolulu: Division of State Parks, Outdoor Recreation and Historic Sites, Department of Land and Natural Resources.

Tomonari-Tuggle MJ. n.d. Archaeological research in north Kohala, 1972-1981. In: Unpublished Мanuscripts, Archaeology Laboratory. Honolulu: University of Hawaii, Mānoa.

Tuggle HD. 1976. Windward Kohala-Hamakua Archaeological Zone, Island of Hawai 'i. Honolulu: University of Hawaii, Mānoa.

Tuggle HD, Griffin JB. 1973. Lapakahi, Hawaii: Ar- 
chaeological Studies. APAS 5. Honolulu: Social Sciences Research Institute.

Tuggle HD, Spriggs M. 2002. The age of the Bellows Dune Site O18, O'ahu, Hawai' $i$, and the antiquity of Hawaiian colonization. Asian Perspectives 39(1-2):
$165-88$.

Tuggle HD, Tomonari-Tuggle MJ. 1980. Prehistoric agriculture in Kohala, Hawaii. Journal of Field Archaeology 7:297-312. 